http://dx.doi.org/10.1007/s11356-012-1285-2

(C) 2012, Springer-Verlag Berlin Heidelberg

The original publication is available at http://www.springerlink.com

\title{
A multibiomarker approach on the Atlantic tomcod (Microgadus tomcod) in the St. Lawrence Estuary
}

\author{
Célie Dupuy ${ }^{1,2,{ }^{*}}$, Catherine M. Couillard ${ }^{3}$,Jean Laroche ${ }^{1}$, Pierre Nellis ${ }^{3}$, Pauline Brousseau $^{2}$ \\ and Michel Fournier ${ }^{2}$
}

\footnotetext{
${ }^{1}$ Université Européenne de Bretagne, Université de Bretagne occidentale, UMR 6539 CNRS/UBO/IRD/Ifremer, Laboratoire des Sciences de l'Environnement Marin LEMAR, Institut Universitaire Européen de la Mer, 29280, Plouzané, France

${ }^{2}$ Institut National de la Recherche Scientifique-Institut Armand-Frappier (INRS-IAF), 31 Des Prairies Blvd., Laval, QC, Canada, H7V 1B7

${ }^{3}$ Pêches et Océans Canada, Institut Maurice Lamontagne, 850 route de la mer, Mont-Joli, QC, G5H 3Z4, Canada
}

*: Corresponding author : Célie Dupuy, email address : cel.e@hotmail.fr

\begin{abstract}
:
A multibiomarker approach was developed on juvenile Atlantic tomcod (Microgadus tomcod) to evaluate the pertinence of this approach for low-cost screening assessment of the environmental quality of various coastal sites within estuaries. Several biometric indices and biomarkers (ethoxyresorufin-O-deethylase (EROD) activity, metallothionein concentration, and immune responses) were investigated on immature and maturing tomcods ( $\leq 31$ months) collected in four environmentally contrasted sites in the St. Lawrence Estuary (SLE). Simultaneous examination of various age classes provides the opportunity to detect short-term responses in sensitive young-of-theyear fish (e.g., EROD induction) and longer-time effects associated with chronic exposure and bioaccumulation (e.g., metallothionein induction). Principal component analysis was helpful to discriminate between responses possibly related to contaminant exposure (EROD, metallothionein) and responses that could be affected by upstream-downstream gradient (immune response, biometric indices). Measurement of a battery of biomarkers in young tomcods at several sites along the shore of the SLE is a low-cost screening investigation useful to identify hot spots requiring further investigation with chemical analysis and additional reference sites.
\end{abstract}

Keywords: Biometric indexes ; EROD ; Metallothionein ; Immunotoxicity ; Pollution ; Fish 


\section{Introduction}

Smith et al. (1979) had detected a high prevalence of hepatocellular carcinomas for the Atlantic tomcod (Microgadus tomcod) in Hudson River (USA), possibly related to elevated concentrations of polycyclic aromatic hydrocarbons (PAHs) and halogenated aromatic hydrocarbons (HAHs) such as polychlorinated biphenyls (PCBs) and polychlorinated dibenzo-p-dioxins/furans (PCDD/Fs). During the forty next years, the Atlantic tomcod has been considered as a candidate species to monitor the quality of estuarine waters in Canada (Couillard 2009), whereas resistance to HAHs and susceptibility to PAHs were demonstrated for the Hudson River's tomcod population (Sorrentino et al. 2005; Yuan et al. 2006).

More recently, Wirgin et al. (2011) demonstrated the major role played by the AHR in the tolerance of tomcod to chemical stress; the Hudson River population exhibiting a particular allele of AHR2 encoding an AHR protein characterized by reduced affinity for dioxin-like compounds; this variant being not detected in other estuaries in the United States or in Canada. Thus in the previous study, a structural change in the coding region of a single gene could explain the resistance of the population. The authors suggested that the fish bioaccumulation of high levels of xenobiotic, associated with low gene flow between populations and strong selective pressure have conducted to a rapid evolutionary change of AHR2 in the Hudson River population.

In Canada (St Lawrence Estuary) tomcod populations are generally submitted to a lower level of contamination compared to the Hudson River population, and do not exhibit the HAH resistance AHR2 allele demonstrated in the Hudson River (Wirgin et al. 2011). Thus, an experimental exposure to PCB77 induced an activation of the CYP1A mRNA expression for Canadian tomcod populations vs no alteration of the expression level for the Hudson River population (Yuan et al. 2006). These confirmed the hypothesis of Wirgin et al. (1994) that Canadian tomcod populations could be more sensitive to lower levels of pollution, compared to the Hudson River population. Several biomarkers measured on mature adult tomcod in Canada have been correlated to pollution level (Couillard et al. 1999; Couillard et al. 2004). In 1994, multifocal granulomatous lesions in the spleen, likely caused by an infectious agent, and density and surface area of pigmented macrophage aggregates were higher in tomcod sampled in the Miramichi Estuary, (NB, Canada) receiving pulp and paper mill effluent compared to a reference estuary (Couillard et al. 1999). Adult tomcods collected in St. Lawrence Estuary (SLE, QC, Canada) and exposed to high levels of organochlorine contaminants including PCBs showed high levels of DNA adducts and hepatocellular proliferations and low hepatic EROD (Ethoxyresorufin-O-deethylase) activity, compared to fish from two estuaries with a lower level of organochlorine contamination (Couillard et al. 2005). Furthermore, Lair et al. (1997) also identified jaw ulcers in tomcods from the SLE, but the cause(s) of these lesions were not identified.

The Atlantic tomcod is an anadromous species; adults undertake yearly migration (up to several hundreds of kilometers) throughout the SLE to spawn in freshwater tributaries (Scott and Scott 1988). In contrast, young-of-the-year (YOY) Atlantic tomcod living in eelgrass meadows are rather sedentary and may better represent local contamination at their site of capture than adult fish as shown previously in the Hudson Estuary (Fernandez et al. 2004) Thus, in this study, we have collected juvenile tomcods in four sites along the SLE: Sept-Îles, Penouille, Cacouna, Rivière-Ouelle.

The Sept-Îles Bay is characterized by numerous industrial and harbor activities and thus probably submitted to a high chemical stress induced by a complex mixture of xenobiotics; some analysis indicating high levels of total Butyltins (BTs) in the benthic invertebrates (about 120ng Sn /g d.w.) and fish (222ng Sn /g d.w.) in this area compared to other sites in SLE (benthic invertebrate between 40 and $60 \mathrm{ng} \mathrm{Sn} / \mathrm{g}$ d.w. and benthic fish between 50 and 
120 ng Sn /g d.w.) (Michaud and Pelletier 2006). Furthermore, sediments near the harbor of Sept-Îles Bay presented high concentrations of arsenic (6 to 13mg/kg) and copper (28 to $38 \mathrm{mg} / \mathrm{kG}$ ); concentrations of arsenic, boron and sulfates in the water of Sept-Îles Bay exceeding the threshold to protect aquatic life (respectively $0.069 \mathrm{mg} / \mathrm{L}, 5 \mathrm{mg} / \mathrm{L}$ and 1499mg/L) (GENIVAR 2012).

Penouille, located in a Bay is displaying a contamination mainly linked to the anthropogenic activities of the city of Gaspé (presence of PCBs, PAHs), but also resulting from mining activities in the river basin and thus showing significant levels of heavy metals like copper (Gagnon 1997; Xstrata Copper Canada 2012). The mine was closed in 1999 and a rehabilitation of the Bay of Gaspé is carried out (removing of contaminated sediments near study site) (Xstrata Copper Canada 2012).

The sites of Rivière-Ouelle and Cacouna could be considered as pristine areas, their basins receiving reduced inputs of domestic, agricultural and industrial effluents. Furthermore, these two sites are not located in bays and thus submitted to a higher mixing with the water of the SLE, compared to the two previous polluted systems. Thus, a fish re-introduction is currently conducted in the Rivière-Ouelle site and the Cacouna site (located between harbour of Cacouna and the Isle Verte) is considered as a major nursery for birds and several fish species (Saint-Louis et al. 1997; Gagnon 1998).

In the present study, an integrative approach on the fish responses to chemical stress was conducted considering several biomarkers (activities of detoxification, immunocompetence, biometric indexes). The major objective was to assess the potential of YOY tomcod as sentinels to explore the water quality in contrasted environments in the SLE.

\section{Materials and methods}

\subsection{Fish sampling and cells preparation}

Tomcods were collected by a hoop net in September-October 2010 in four eelgrass meadows in Québec (Fig. 1): Cacouna $(n=39)$, Rivière-Ouelle $(n=60)$, Sept-îles $(n=33)$ and Penouille $(n=44)$. Fishes were killed by cervical dislocation, just after the catch. Their total length, gutted-carcass weight, liver weight and gonads weight were measured. The liver and a part of muscle were flash-frozen and stored at $-80^{\circ} \mathrm{C}$. Otoliths were removed for ageing.

The head kidney of each fish was aseptically removed. Pronephric cell suspensions were obtained by homogenization of head kidney with a syringe valve against a steel grid with $1 \mathrm{ml}$ of medium. The medium used throughout the assays, consisted of steril RPMI 1640 supplemented with $10 \%(\mathrm{v} / \mathrm{v})$ fetal bovine serum (FBS) from Biomedia (Montreal, Quebec, Canada), $0.5 \mathrm{mg} / \mathrm{mL}$ sodium pyruvate, penicillin $(100 \mathrm{U} / \mathrm{mL}) /$ streptomycin $(100 \mathrm{mg} / \mathrm{mL})$, and buffered with $10 \mathrm{mM}$ Hepes (pH 7.4) (Brousseau et al. 1999). Cells were counted with hemocytometer by the microscope, using trypan blue dye exclusion $(0.4 \%)$. Viability was over $90 \%$.

\subsection{Biometric indexes}

The individual fish age was estimated considering that all fishes were born in February in a SLE tributary (Fortin et al. 1990); the number of winter being detected on the otoliths by a binocular.

The body condition factor (CF) was calculated by the formula: $C F=100 \times \mathrm{W} / \mathrm{L}^{3}$, where $\mathrm{W}$ is gutted-carcass weight $(\mathrm{g})$ and $\mathrm{L}$ is total fish length $(\mathrm{mm})$. 
The hepatosomatic index (HSI) was calculated as: $\mathrm{HSI}=100 \times \mathrm{LW} / \mathrm{W}$, and gonadosomatic index (GSI) as: GSI $=100 \times$ GW/W where W is gutted-carcass weight (g), LW is liver weight (g) and $\mathrm{GW}$ is gonad weight $(\mathrm{g})$.

Frequency of GSI distribution, for males as females, was used to classify the fish into two groups: immature fishes with low GSI and maturing fishes with higher GSI (data not shown). All indices were then calculated for each group separately.

\subsection{Detoxification}

\subsubsection{EROD (ethoxyresorufin-O-deethylase)}

EROD activity was measured at $22^{\circ} \mathrm{C}$ by a microplate spectrofuorometric assay (excitation $530 \mathrm{~nm}$, emission $585 \mathrm{~nm}$ ) in the liver S9 fraction (Couillard et al. 2004). Protein concentrations were determined by the method of Bradford using bovine serum albumin as a standard (BIO-RAD Laboratories, USA).

\subsubsection{Metallothionein}

A metallothionein(MT)-specific antibody and flow cytometry were used to determinate the relative cellular level of metallothionein in immune cells as described by Yurkowi and Makhijani (1998). Briefly, pronephric cell suspensions were fixed with phosphate buffered saline (PBS, $\mathrm{pH} 7.4$ ) with $0.3 \%$ of paraformaldehyde. One million cells were washed at 1200G, $5 \mathrm{~min}$ and $500 \mu \mathrm{l}$ of permeabilization buffer (PBS with $3 \%$ foetal calf serum, $0.1 \%$ sodium azide and $0.1 \%$ saponine, $\mathrm{pH} 7.4$ ) was added on the pellet. After $30 \mathrm{~min}$ of incubation, $500 \mu \mathrm{l}$ of staining buffer (PBS with $3 \%$ foetal calf serum, $0.1 \%$ sodium azide, $\mathrm{pH}$ 7.4 ) were added. Cells were centrifuged at $1200 \mathrm{G}, 5 \mathrm{~min}$. Specific anti-MT monoclonal mouse antibody (DAKO-MT-E9, Dako Canada Inc., Burlington, Ontario, Canada) was added on the cells $\left(1 \mu \mathrm{g}\right.$ of antibody to $1.10^{6}$ cells) and incubated $30 \mathrm{~min}$ at ambient temperature. Cells were washed with staining buffer and an anti-mouse IgG antibody (Fab specific, $F\left(a b^{\prime}\right) 2$ fragmentFITC antibody (Sigma-Aldrich Canada Ltd) was added on the pellet (10 $\mu \mathrm{l}$ of a 1:100 dilution of conjugate per $10^{6}$ cells). After washing the cells (centrifugation at $1200 \mathrm{G}, 5 \mathrm{~min}$ ), the pellet was re-suspended in PBS. Cells were analyzed by flow cytometry (FACSCalibur cytometer, Becton Dickinson, San José, USA) and 10000 events were recorded. The relative cellular MT concentration is estimated by mean fluorescence intensity of macrophage population.

\subsection{Immunology}

\subsubsection{Phagocytosis}

Capacity of phagocytosis was assessed by the methods described by Brousseau et al. (1999). Briefly, fluorescent latex beads $(d=1.7 \mu \mathrm{m}$, Polysciences, Warrington, USA) were added to pronephric cell suspensions $\left(10^{6} \mathrm{cell} / \mathrm{sl}\right)$ in order to respect the $100: 1$ beads to cell ratio. The cells were incubated $18 \mathrm{~h}$ at ambient temperature $\left(20^{\circ} \mathrm{C} \pm 1\right)$. Then, cell suspension was layered over a $3 \%$ bovine serum albumin gradient and cells recovered by centrifugation at $150 \mathrm{~g}$ for $8 \mathrm{~min}$ in order to remove the free beads. Cell pellets were then resuspended in $0.5 \mathrm{ml}$ of $0.5 \%$ formaldehyde and $0.2 \%$ sodium azide diluted in phosphate buffer saline (PBS). Cells can be kept in one week. Cells were analyzed by flow cytometer (FACSCalibur cytometer, Becton Dickinson, San José, USA) and 10000 events were recorded. The efficiency of phagocytosis was determined by the percentage of cells having three or more beads in macrophage gate. 


\subsubsection{Cell cycle analysis}

Proliferation of lymphocytes was estimated by flow cytometry assay based on the analysis of cell cycle through the quantification of DNA content (Chilmonczyk and Monge 1999; Nunez 2001). Pronephric cell suspensions $\left(1 \mathrm{ml}\right.$ of $\left.10^{6} \mathrm{cells} / \mathrm{ml}\right)$ were fixed with ethanol and stored at $4^{\circ} \mathrm{C}$. For analysis, cells were centrifugated $(5 \mathrm{~min}, 450 \mathrm{G})$ and were resuspended in PBS $\left(0,5.10^{6} \mathrm{cells} / \mathrm{ml}\right)$. Each sample was recentrifugated $(5 \mathrm{~min}, 450 \mathrm{G})$ and resuspended in $500 \mathrm{ml}$ of PBS with RNase $(10 \mu \mathrm{g} / \mathrm{ml})$ ans propidium iodide $(50 \mu \mathrm{g} / \mathrm{ml})$. Cells were incubated at room temperature during $30 \mathrm{~min}$. Cells were analysed by FACSCalibur cytometer (Becton Dickinson, San José, USA), 10000 events were recorded and doublet cells were subtracted (Wersto et al. 2001). Percentage of lymphocytes and macrophages in G0/G1, S and G2/M were acquired by DNA content analysis (represent by the red fluorescence intensity due to propidium idodide) of lymphocyte and macrophage gate.

\subsection{CCO (Cytochrome C oxidase)}

CCO activity was measured at $22^{\circ} \mathrm{C}$ by a microplate spectrophotometric assay in muscle S9 fraction (Smith and Conrad 1956; Théron et al. 2000). Absorbance changes were monitored at $550 \mathrm{~nm}$ during $8 \mathrm{~min}$. Protein concentrations were determined by the method of Bradford using bovine serum albumin as a standard (BIO-RAD Laboratories, USA). CCO is the complex IV of electron transport chain in mitochondria and is responsible for $90 \%$ of cellular oxygen consumption in mammals (Xu et al. 2005).

\subsection{Statistical analyses}

Statistic tests and box plot graphs were carried out using Statistica 10.0 (StatSoft). The variables were not normally distributed, so the Kruskal-Wallis (KW) test was used for intersites comparisons for immature and maturing fishes separately. Within sites, immature and maturing fishes were also compared by KW test. When KW test was significant $(p \leq 0.05)$, it was followed by a post-hoc test: a multiple bilateral comparisons of mean ranks. No significant differences between males and females was detected over the whole markers (KW test: $p>0.05$ ); thus the analysis were conducted grouping males and females.

Principal Component Analysis (PCA) was used to explore the variability of the different fish markers over the sampling sites. Markers of cell cycle were strongly correlated, thus only the percentage of lymphocytes on G2/S phase was considered in the PCA. HSI and GSI were strongly dependent of maturity and/or gender and/or fish age, thus these two indices were not considered. Finally, CF, EROD, MT, lymphocytes on G2/S phase, phagocytosis and CCO were considered in the PCA. All data were standardized (zero mean, unit variance) before PCA.

\section{Results}

\subsection{Biometric indices}

YOY (8-9 months), one-year-old (20-21 months) and two-years-old (32-33 months) tomcods were caught at each sampling site (Fig. 2). Fishes sampled in Sept-îles and Penouille showed higher total length and condition factor compared to those of Rivière-Ouelle and Cacouna (Fig. 2 \& 3A). 
Whatever the considered site, the GSI of maturing females (males: data not showed) was higher than the one of immature fishes (Fig. 3B); however the increase of GSI linked to the maturation process appeared more limited in Penouille compared to other sites.

Immature fishes showed lower HSI than maturing fishes, this difference being only significant in Rivière-Ouelle (Fig. 3C); furthermore, the HSI of fishes in maturation was significantly higher in Cacouna vs Rivière-Ouelle and Penouille (Fig. 3C).

\subsection{Detoxification}

\subsubsection{EROD (ethoxyresorufin-O-deethylase)}

No significant difference was detected between males and females for EROD activity within site (KW test: $p>0.05$ ), thus the data were pooled by site (Fig. 4A). In Cacouna, EROD activity was higher for immature compared to maturing tomcods. In addition, immature tomcods displayed a higher EROD activity in Penouille compared to other sites; no significant difference was detected between sites for maturing tomcods (Fig. 4A).

\subsubsection{Metallothionein}

No significant difference of MT concentration was detected among sampling sites for immature tomcods (Fig. 4B). However a particularly high inter-individual variability was observed for this biomarker in Penouille. The MT concentration differed among sites only for maturing fishes, tomcods in Rivière-Ouelle, and in Sept-Îles/Penouille showing respectively the lowest and the highest values (Fig. 4B). In Penouille, significantly more MT was detected in maturing than in immature tomcods.

\subsection{Immunology}

No significant difference of immune responses (cell cycle or phagocytosis activity), was detected between immature and maturing tomcods, whatever the sampling site (Fig. 5A \& $5 B)$.

\subsubsection{Cell cycle analysis}

Over the whole data set, the percentage of cells in G0/G1 phase was strongly and negatively correlated with the one of cells in $G 2 / M$ phase $(R=-0.93, p<0.001)$. In Sept-Îles and Penouille, tomcods showed a significantly higher percentage of cells in G2/M (and lower percentage of cells in G0/G1) relatively to those in Rivière-Ouelle and Cacouna (Fig. 5A).

\subsubsection{Phagocytosis}

Fishes in Rivière-Ouelle and Cacouna displayed a higher capacity of phagocytosis than those of Sept-Îles and Penouille; the phagocytosis activity being particularly reduced in Penouille for immature as maturing fishes (Fig. 5B). 


\section{4. $\mathrm{CCO}$}

Activity of CCO showed a high within site variability. No significant difference was detected for the CCO activities over the different sites $(0.54 \pm 0.35<$ mean \pm SD $<0.83 \pm 0.31)$

The results were not presented because no significant difference was detected among sites, sexes, maturity classes or age.

\subsection{PCA}

The first and second principal components (axis 1 \& axis 2) accounted for respectively $34.49 \%$ and $21.6 \%$ of the total variance over the whole data set (Fig. 6 ). On the first axis of the correlation circle, an opposition was observed between the right side of the diagram mainly characterized by a high phagocytosis activity and the left side principally linked to high condition index and \% of lymphocytes in G2/M phase (Fig. 6). The second axis was mainly linked to detoxification activities, the upper and lower parts of the plan being characterized respectively by a high EROD activity and a high concentration of MT.

On the distribution of the individuals on the main factorial plan (Axis $1 \& 2$ ), two groups of fishes were clearly detected (Fig. 7):

- on the left part of the plan, a mixture of individuals from Penouille and Sept-Îles displaying a reduced capacity of phagocytosis, high percentage of cells in G2/M phase and high CF; upper and lower fishes displaying respectively a high activity of detoxification by EROD and by MT;

- on the right part of the plan, a mixture of individuals from Rivière-Ouelle and Cacouna showing a high capacity of phagocytosis, a reduced percentage of cells in G2/M phase, a reduced CF and a limited activity of detoxification (EROD or MT) explaining their reduced spatial distribution over the axis 2;

- Furthermore, the fish group: (Cacouna and Rivière-Ouelle) showed a higher CCO activity relatively to the group (Penouille and Sept-îles).

\section{Discussion}

In the past, most biomarkers assessed in Atlantic tomcod were measured in liver: liver histopathology (Smith et al. 1979; Cormier et al. 1989; Johnson et al. 1993; Couillard et al. 1999), hepatic DNA adducts (Wirgin et al. 1994), EROD activity (Couillard et al. 2005) and the expression of genes, mainly the CYP1A (Wirgin et al. 1994; Williams et al. 1998; Yuan et al. 2001; Couillard et al. 2004; Sorrentino et al. 2005; Yuan et al. 2006; Carlson et al. 2009). These earlier studies were focused mostly on HAHs toxicity. In the present study, an integrative approach was conducted on the responses of the tomcod to the chemical stress (organic and inorganic) exploring biometric indices, biomarkers of detoxification and of immunocompetence, in four contrasted environments in the SLE including two displaying mixed sources of contamination. Earlier studies in the SLE used adult fish whereas our studies use YOY and subadults (from 8 to 33 month old fish) to explore the tomcod responses at different sites within a single estuary. We suggest that these young fish can be impacted by the chemical stress in estuaries and thus could response to the contamination at different levels of biological organization (molecular, biochemical, cellular and organism levels) as it was previously observed for juvenile fish like tomcod or European flounder, respectively in North-West and North-East Atlantic (Wirgin and Waldman 1998; Evrard et al. 2012) 


\subsection{Biometric indexes}

To distinguish the natural variability (noise) and contaminant-induced stress (signal), the baseline data of a biomarker/bioindicator should be well defined (van der Oost et al. 2003). Williams et al. (1998) measured CF, HSI and GSI during one year on mature Atlantic tomcods in a reference site and an area polluted by pulp and paper effluents. The biometric indices in the reference as in the contaminated sites varied along the annual reproductive cycle between 0.55 and 0.85 for the CF, between 2 and 7 for the HSI, and between 3 to 6 for females and 1 to 5 to males considering the GSI. CF and HSI were maximal in the fall (September-November) and minimal during the spawning period (February-March). In contrast GSI was maximal in February and minimal in May. Other studies on mature Atlantic tomcod sampled yearly in early spring from 1998 to 2004 in the SLE, showed that CF can vary between the years from 0.45 to 0.75 (Couillard et al. 2004).

In the present study, maturing tomcods of Penouille showed higher CF value compared to reference sites in the bibliography. Thus, CF does not appear to be negatively impacted by chemical stress and may be more influenced by natural factors (Linde-Arias et al. 2008). Condition factor of fishes can be modified by various factors including bathymetry (Chouinard and Swain 2002), abundance of prey (Dutil et al. 2003), salinity (Lambert et al. 1994), age, sex and climate (Lambert and Dutil 1997; Guimaraes et al. 2009). Penouille site is probably characterized by a contrasted hydroclimatic conditions relatively to the other sites in the SLE, considering particularly the thermal regime and the onset of sea ice (Villeneuve 1959; Saucier et al. 2003). These differences can directly impact the metabolism of tomcod, and also its growth rate as observed in the present study where the growth appeared higher at the downstream sites (Penouille/Sept-îles) compared to the upstream sites (Cacouna/Rivière-Quelle). Density-dependent processes could also be involved. Furthermore, the local hydroclimatic conditions and habitat physicochemical characteristics can also modify the availability of prey and consequently the tomcod energy allocation. Finally, it is possible that the populations of tomcod sampled downstream in the SLE are genetically distinct from those sampled upstream and their genetic could affect energy allocation.

Variation in GSI (considering females) is primary explained by the reproductive cycle (Williams et al. 1998). Maturing tomcods of Cacouna and Rivière-Ouelle (collected in October) showed higher GSI compared to those of Sept-îles and Penouille (collected in September); thus, the differential between the sampling periods could explain that Cacouna and Rivière-Ouelle fishes should be more advanced in their reproductive cycle and could explain their contrasted GSI. However we suggest, particularly for the Penouille site, that the very limited increase of GSI from immature to maturing fishes could be related to a toxic effect of pollutants. In these fish, more energy could be allocated to storage than to reproduction. Complementary observations on the reproduction biology should be conducted in this site, considering an annual change in ovarian histology and steroid profiles at Penouille and in a reference site with similar hydroclimatic and habitat characteristics.

Maturing tomcods in Cacouna showed higher HSI compared to other sites. Xenobiotics exposure can lead to induction of hepatic enzymes, liver inflammation or abnormal growth (Olivares et al. 2010). Higher HSI could be explained by the increase of cell size or cell number as a response to pollutants (van der Oost et al. 2003). Maturing tomcods in Cacouna did not show any induction of EROD activity (see 4.2), thus their high HSI does not seem to be a consequence of enzymatic induction. The gadidae store their lipid reserves in liver (Lambert and Dutil 1997) and fat reserves are transferred from liver to gonads at the time of maturation. Vitellogenesis also occurs in liver during gonad maturation. We suggest that the highest HSI in maturing fish in Cacouna could be a consequence of their more advanced 
maturation. Finally, in the present study, no obvious relationship was detected between the $\mathrm{HSI}$ and the level of pollution, considering the immature as the maturing tomcods.

\subsection{EROD (ethoxyresorufin-o-deethylase) and MT (metallothionein)}

Hepatic EROD induction is commonly considered as a pertinent indicator of exposure to molecules binding to the arylhydrocarbon receptor such as PAHs and HAHs (van der Oost et al. 2003). Several studies have demonstrated a significant increase of EROD activity for animals living in polluted sites (e.g. Xu et al. 2002; Aarab et al. 2004; Fasulo et al. 2010).

In several fish species, EROD induction, particularly for females, was dependent on the stage of maturity and thus could explain a differential between males and females (e.g. Kirby et al. 1999; Khan and Payne 2002; Miller et al. 2004). We suggest that the absence of difference in the EROD activity between genders in the present study could be linked to the sampling period of tomcods, at the beginning of their reproductive cycle (Williams et al. 1998). An absence of difference between males and females EROD activity has been reported occasionally for other fish species (Flammarion et al. 2002; Fang et al. 2010; Gungordu and Ozmen 2011)

In the present study, in two sites (Cacouna and Penouille), YOY tomcod displayed a higher EROD activity compared to maturing fishes, the median values being respectively 3 and 0.5 $1 \mathrm{pmol} / \mathrm{min} / \mathrm{mg}$. Lower EROD activity in maturing fish could reflect differential exposure as a result of different diet or of bioaccumulation of chemicals with age. Dietary shift from zooplanktom to macroinvertebrates in the first year of age has been reported in Hudson Estuary tomcod (Fernandez et al. 2004). Lower EROD activity in older maturing fish could be related to natural selection for less-inducible genotypes (Wirgin et al. 2011) or to suppression of CYP1A activity by steroid hormones (Williams et al. 1998) or by bioaccumulated xenobiotics (e.g. Couillard et al. 2004, EROD levels being 2-9 and $0.6-5 \mathrm{pmol} / \mathrm{min} / \mathrm{mg}$ for repectively $1+$ tomcods and older fish). This hypothesis could be strengthened particularly for the Penouille site where a significant contamination by complex mixture of pollutants is suspected (Gagnon 1997; Xstrata Copper Canada 2012); this type of contamination being a strong inhibitor of EROD activity (Viarengo et al. 1997; Kerambrun et al. 2012). Furthermore in the SLE, Couillard (2009) underlined a negative correlation between the level of hepatic EROD activity and the organochlorine concentration, considering adult tomcods; the average level of EROD activity being repectively of 1 and $10 \mathrm{pmol} / \mathrm{min} / \mathrm{mg}$ for the highly vs lowly contaminated fish.

Finaly the present study confirmed that there are obviously many gaps in our knowledge on the tomcod EROD activity. Further studies are needed to compare exposure of YOY and maturing tomcod to different classes of inducing or inhibiting xenobiotics or to explore the hypotheses of post-transcriptional inhibition of EROD activity or natural selection. The variability of this biomarker is potentially linked to multiple factors and could be inhibited by the pollutants, thus the EROD induction used alone must be considered cautiously for the diagnostic of the water quality in the field.

MT is a protein which plays a major role in the protection against the toxic effects of heavy metals (George and Olsson 1994). MT shows a sequestering function explained by the binding of MT to particular metals (Klaassen et al. 1999). Several laboratory experiments underlined that teleost MT's are inducible by numerous metals like cadmium, copper, zinc (George and Olsson 1994; van der Oost et al. 2003). In this study, the relative quantity of MT was estimated by an immunoassay technique, considered as the most sensitive method for the quantification of MT proteins (George and Olsson 1994). 
In the present study, a significant increase of MT was clearly detected in maturing tomcods of Penouille and Sept-Îles compared to those of Cacouna and Rivère-Ouelle; this trend being not detected for the immature fishes. We suggest that maturing fishes have bioaccumulated more metals in their tissues; the higher bioaccumulation for older fishes conducting to MT induction; this trend being also detected for coastal fishes submitted to metallic pollution (Rotchell et al. 2001; Marijić and Raspor 2006). The Penouille and Sept-Îles sites were clearly suspected to show a chronic metallic contamination; thus their higher MT levels suggest that this biomarker could become an efficient tool for the diagnostic of heavy metals exposure in estuarine waters.

\subsection{Immunology}

Immunocompetence might be considered as a pertinent biomarker of exposure to environmental stress (Burnett et al. 2007). Several xenobiotics can conduct to an immunosuppression but conflicting results indicated a difference in sensitivity according to the species tested, the concentrations used, and the time and/or exposure route (SanchezDardon et al. 1999). The exposure of animals to contaminants in the field could lead to suppression, inhibition of immune competence and / or stimulation, hypersensitivity and autoimmune reaction (Sweet and Zelikoff 2001). Capacity of phagocytosis is widely used in ecotoxicology, considering particularly fishes and mollusks (Bols et al. 2001; van der Oost et al. 2003). Several toxics can inhibit the activity of macrophages leading to a decrease of their phagocytosis capacity (Fournier et al. 2000; Bols et al. 2001). Measures of cell cycle by flow cytometer allowed to estimate the lymphocyte proliferation (Chilmonczyk and Monge 1999). Some toxics might inhibit (e.g. Payette et al. 1995) or enhance the proliferation (e.g. Low and Sin 1998). Low and Sin (1998) have demonstrated that low and high concentrations of mercury respectively enhance and inhibit the proliferation of lymphocytes.

The result of immune biomarkers on tomcod showed clearly two groups of sites in the SLE. The tomcods from the upstream sites (Rivière-Ouelle and Cacouna) displayed a high capacity of phagocytosis and few lymphocytes in G2/S phase compared to fish from the upstream sites (Sept-îles and Penouille), with a lower capacity of phagocytosis and more lymphocytes in G2/S phase (i.e. an increase of proliferation for these two last sites). These responses may seem conflicting but they were also reported in other studies, the responses of immune system to complex mixture being difficult to predict (Tahir and Secombes 1995; Burnett et al. 2007; Finkelstein et al. 2007). Generally, chemical exposure can interfere with critical phases of the fish immunity by blocking phagocytic activity, inducing or inhibiting cell proliferation, or negating precursor cell formation (Sweet and Zelikoff 2001).

Numerous xenobiotics can modulate the immune function, particularly the heavy metals (Bernier et al. 1995; Sanchez-Dardon et al. 1999; Fournier et al. 2000); the underlying mechanisms being not clear. Toxics could affect directly the immune system, for example by inducing the apoptosis of immune cells. The presence of toxics in an organism can also induce the production of stress hormones which can modulate the immune system (Bols et al. 2001). In tomcods from Sept-Îles and Penouille, measures of MTs were also carried out on head kidney and showed that pronephric cells responded to heavy metals. We suggest that the presence of heavy metals and possibly of other pollutants induces several significant alterations of the tomcod immune system in these polluted sites, inhibiting its capacity of phagocytosis and enhancing the proliferation of lymphocytes. On the long range, these alterations could reduce the efficiency of the immune system and as a consequence, could increase the disease susceptibility (Arkoosh et al. 1998; Arkoosh et al. 2001). Alternative hypotheses are modulation of the immune response by natural upstream-downstream ecological gradient or by the reproductive cycle. Further studies with fish sampling at reference sites with similar ecological characteristics than Penouille and Sept-îles and chemical analyses would be necessary to discriminate among these various hypotheses. 
Again, the variability of this biomarker is potentially linked to multiple factors, thus the immune response used alone must be considered cautiously for the diagnostic of the water quality in the field.

\section{4. multibiomarker approach}

In a multibiomarker approach, the major objectives are to investigate markers that complement each other and adequately explain the differences between the study sites (Humphrey et al. 2007). In the present study, the main factorial plan of the PCA, explained $56 \%$ of the total variance of the data set and thus gives a global vision on the variability of biomarkers and fish distributions over the different sampling sites along the St Lawrence estuary. The first PCA axis was mainly explained by the immune markers and by the condition index (phagocytosis vs CF - percentage of G2/M phase lymphocytes); the second axis being associated to detoxification activities (EROD vs MT).

The fish distribution on the main factorial plan shows a clear separation of the upstreamsites (Rivière-Ouelle and Cacouna) where the fishes showed a better capacity of phagocytosis, a low number of cells in G2/M, a lower CF and limited detoxification activites (EROD and MT). We suggest that these sites are probably submitted to a reduced pollution, considering (1) their obvious reduced inputs of domestic, agricultural and industrial effluents and (2) the highly probable dilution effect of the SLE water in these "open systems" (i.e. non located in Bays).

On the other hand, the fishes of the downstream sites (Sept-îles and Penouille) showed globally a lower capacity phagocytosis, more cells in G2/M and higher CF, EROD activities and metallothionein levels; this second fish group was probably living in heavily polluted bays displaying complex mixtures of contaminants. We suggest that the higher fish spatial distribution over the axis 2 of the PCA in the downstream vs upstream populations underlines a higher variability of the detoxification activities (EROD activity and metallothionein level) linking to the fish aging in polluted vs in pristine systems.

\section{Conclusion}

In the present study, several biomarkers were explored on the Atlantic tomcod in contrasted environments of the SLE, the downstream sites displaying higher inputs of anthropogenic effluents when compared to upstream sites. Higher growth rate and condition factor in the two downstream sites (Penouille and Sept-Îles) vs upstream-sites (Cacouna, Rivière Ouelle) could be more related to ecological gradient than to contamination level. A reduced energy allocation for reproduction in maturing fish at Penouille could have detrimental consequences for fish reproduction and warrants further investigation on sexual maturation process and potential endocrine disruption at this site.

EROD and MT are linked to detoxification and are considered as biomarkers of exposure to pollutants. However, with the aging of the fish in the more polluted systems, the bioaccumulation of xenobiotics could inhibit the EROD activity but on the other hand should be necessary to induce the production of MT. The capacity of phagocytosis and the cell cycle analysis are indicators of the immune function that could affect the susceptibility of individuals to infectious agents (Bols et al. 2001). In the present study, complex mixtures of contaminants in the downstream polluted systems could induces significant alterations of the tomcod immune system (inhibition of phagocytosis and proliferation of lymphocytes). 
Further investigations will be necessary to thoroughly analyze the tomcod responses in habitats displaying contrasted levels of contamination but also differential hydroclimatic conditions. A better understanding of the possible role of the confounding factors (i.e. not directly linked to the chemical stress) on the modulation of biomarkers is needed. Chemical analysis should be conducted in sediments, preys and tomcod tissues to better characterize differential exposure of various age classes of tomcods at different sites. Thus, we suggest to study in the future the basic life cycle and the physiology of the tomcod in different regions of the SLE, as well as the seasonal baseline levels in the biomarkers, in addition to pollutant load in these locations. Finally, we suggest that the tomcod population genetics should be explored, to assess the possibility of gene flow between different sites and of genetic adaptation over the SLE.

\section{Acknowledgments}

This work was conducted in the environmental immunotoxicology laboratory at Institut Armand Frappier (IAF-INRS). Financial support has been provided by the Canada Research Chair in Environmental Immunotoxicology (Dr. Michel Fournier) and Collège Doctoral International de l'Université européenne de Bretagne. Authors also thank S. Gauthier-Clerc, Agence Mamu Innu Kaikusseht, the staff of Parc national Forillon and of the Ministère des Ressources naturelles et de la Faune du Bas-Saint-Laurent for field sampling. The authors tank Marlene Fortier and Benoît Légaré for her technical assistance. Many thanks to an anonymous referee for his pertinent comments on the draft of this paper. This study was also supported by the INTERREG IV program (DIESE): $50 \%$ of the PhD grant was obtained by the first author, for the development of immune markers in ecotoxicology.

\section{References}

Aarab N, Champeau O, Mora P, Daubeze M, Garrigues P, Narbonne JF (2004) Scoring approach based on fish biomarkers applied to French river monitoring. Biomarkers 9 (3):258-270. doi:10.1080/13547500400015626

Arkoosh M, Clemons E, Huffman P, Kagley A, Casillas E, Adams N, Sanborn H, Collier T, Stein J (2001) Increased susceptibility of juvenile chinook salmon to vibriosis after exposure to chlorinated and aromatic compounds found in contaminated urban estuaries. J Aquat Anim Health 13:257-268

Arkoosh MR, Casillas E, Clemons E, Kagley AN, Olson R, Reno P, Stein JE (1998) Effect of Pollution on Fish Diseases: Potential Impacts on Salmonid Populations. J Aquat Anim Health 10 (2):182-190. doi:10.1577/1548-8667(1998)010<0182:eopofd>2.0.co;2

Bernier J, Brousseau P, Krzystyniak K, Tryphonas H, Fournier M (1995) Immunotoxicity of heavy metals in relation to Great Lakes. Environ Health Perspect 103 (Suppl 9)

Bols NC, Brubacher JL, Ganassin RC, Lee LEJ (2001) Ecotoxicology and innate immunity in fish. Dev Comp Immunol 25 (8-9):853-873

Brousseau P, Payette Y, Tryphonas H, Blakley B, Boermans H, Flipo D, Fournier M (1999) Manual of immunological methods. Handbooks in Pharmacology and Toxicolog. CRC Press, Boston, USA

Burnett KG, Bain LJ, Baldwin WS, Callard GV, Cohen S, Di Giulio RT, Evans DH, GómezChiarri M, Hahn ME, Hoover CA, Karchner SI, Katoh F, MacLatchy DL, Marshall WS, Meyer JN, Nacci DE, Oleksiak MF, Rees BB, Singer TD, Stegeman JJ, Towle DW, Van Veld PA, Vogelbein WK, Whitehead A, Winn RN, Crawford DL (2007) Fundulus as the premier teleost model in environmental biology: Opportunities for new insights using genomics. Comparative Biochemistry and Physiology Part D: Genomics and Proteomics 2 (4):257-286. doi:10.1016/j.cbd.2007.09.001 
Carlson EA, Roy NK, Wirgin II (2009) Microarray analysis of polychlorinated biphenyl mixture-induced changes in gene expression among Atlantic tomcod populations displaying differential sensitivity to halogenated aromatic hydrocarbons. Environ Toxicol Chem 28 (4):759-771. doi:10.1897/08-195r.1

Chilmonczyk S, Monge D (1999) Flow cytometry as a tool for assessment of the fish cellular immune response to pathogens. Fish \& Shellfish Immunology 9 (4):319-333. doi:10.1006/fsim.1998.0188

Chouinard GA, Swain DP (2002) Depth-dependent variation in condition and length-at-age of Atlantic cod (Gadus morhua) in the southern Gulf of St. Lawrence. Canadian Journal of Fisheries \& Aquatic Sciences 59 (9):1451

Cormier SM, Racine RN, Smith CE, Dey WP, Peck TH (1989) Hepatocellular carcinoma and fatty infiltration in the Atlantic tomcod, Microgadus tomcod (Walbaum). J Fish Dis 12 (2):105-116

Couillard CM (2009) Utilisation des poissons pour évaluer les effets biologiques des contaminants dans l'estuaire du Saint-Laurent et le fjord du Saguenay / use of fish to assess biological effects of contaminants in the St. Lawrence Estuary and Saguenay Fjord. Revue des sciences de l'eau / journal of water Science $n^{\circ} 22$ (2):291-314 (in French)

Couillard CM, Lebeuf M, Ikonomou MG, Poirier GG, Cretney WJ (2005) Low hepatic ethoxyresorufin-o-deethylase activity correlates with high organochlorine concentrations in Atlantic tomcod from the Canadian east coast. Environ Toxicol Chem 24 (10):2459-2469. doi:10.1897/05-048r.1

Couillard CM, Williams PJ, Courtenay SC, Rawn GP (1999) Histopathological evaluation of Atlantic tomcod (Microgadus tomcod) collected at estuarine sites receiving pulp and paper mill effluent. Aquat Toxicol 44 (4):263-278. doi:10.1016/s0166-445x(98)00085$\mathrm{x}$

Couillard CM, Wirgin II, Lebeuf M, Légaré B (2004) Reduction of cytochrome P4501A with age in Atlantic tomcod from the St. Lawrence Estuary, Canada: relationship with emaciation and possible effect of contamination. Aquat Toxicol 68 (3):233-247. doi:10.1016/j.aquatox.2004.03.012

Dutil J-D, Lambert Y, Chabot D (2003) Winter and spring changes in condition factor and energy reserves of wild cod compared with changes observed during food-deprivation in the laboratory. ICES Journal of Marine Science: Journal du Conseil 60 (4):780-786. doi:10.1016/s1054-3139(03)00024-9

Evrard E, Devaux A, Bony S, Cachot J, Charrier G, Quiniou L, Laroche J (2012) Responses of juvenile European flounder (Platichthys flesus) to multistress in the Vilaine estuary, during a 6-month survey. Environ Sci Pollut Res:1-14. doi:10.1007/s11356-012-1138$z$

Fang JKH, Au DWT, Chan AKY, So LKY, Liu WH, Mok HOL, Yu WY, Wu RSS, Shin PKS (2010) Ethoxyresorufin-O-deethylase enzyme activities and accumulation of secondary/tertiary lysosomes in rabbitfish Siganus oramin as biomarkers for xenobiotic exposures. Sci Total Environ 408 (20):4833-4840. doi:10.1016/j.scitotenv.2010.06.003

Fasulo S, Marino S, Mauceri A, Maisano M, Giannetto A, D'Agata A, Parrino V, Minutoli R, De Domenico E (2010) A multibiomarker approach in Coris julis living in a natural $\begin{array}{lllll}\text { environment. Ecotox } & \text { Environ } & \text { Safe } 1565-1573 .\end{array}$ doi:10.1016/j.ecoenv.2010.01.008

Fernandez MP, Ikonomou MG, Courtenay SC, Wirgin II (2004) Spatial Variation in Hepatic Levels and Patterns of PCBs and PCDD/Fs among Young-of-the-Year and Adult Atlantic Tomcod (Microgadus tomcod) in the Hudson River Estuary. Environ Sci Technol 38 (4):976-983. doi:10.1021/es034177f

Finkelstein ME, Grasman KA, Croll DA, Tershy BR, Keitt BS, Jarman WM, Smith DR (2007) Contaminant-associated alteration of immune function in black-footed albatross (Phoebastria nigripes), a North Pacific predator. Environ Toxicol Chem 26 (9):18961903. doi:10.1897/06-505r.1 
Flammarion P, Devaux A, Nehls S, Migeon B, Noury P, Garric J (2002) Multibiomarker responses in fish from the Moselle River (France). Ecotox Environ Safe 51 (2):145153. doi:10.1006/eesa.2001.2134

Fortin R, Léveillé M, Laramée $P$, Mailhot $Y(1990)$ Reproduction and year-class strength of the Atlantic tomcod (Microgadus tomcod) in the Sainte-Anne River, at La Pérade, Québec. Canadian Journal of Zoology 68 (7):1350-1359

Fournier M, Cyr D, Blakley B, Boermans H, Brousseau P (2000) Phagocytosis as a biomarker of immunotoxicity in wildlife species exposed to environmental xenobiotics. American Zoologist 40 (3):412

Gagnon M (1997) Bilan régional Gaspésie-Sud - Baie des Chaleurs : zone d'intervention prioritaire 20B. Centre Saint-Laurent, (in French)

Gagnon M (1998) Regional Assessment: South Shore of the St. Lawrence Upper Estuary. Priority Intervention Zones 15, 16 and 17. Environment Canada - Quebec Region, Environmental Conservation, St. Lawrence Centre. ,

GENIVAR (2012) Aménagement d'infrastructures portuaires au Port de Sept-Îles, Construction d'un quai multi-usagers à Pointe-Noire - Examen environnemental préalable. (in French)

George SG, Olsson PE (1994) Metallothioneins as indicators of trace metal pollution. In: Kramer KJM (ed) Biomonitoring of coastal waters and estuaries. CRC Press, Boca Raton, pp 151-178

Guimaraes L, Gravato C, Santos J, Monteiro LS, Guilhermino L (2009) Yellow eel (Anguilla anguilla) development in NW Portuguese estuaries with different contamination levels. Ecotoxicology 18 (4):385-402. doi:10.1007/s10646-008-0294-x

Gungordu A, Ozmen M (2011) Assessment of seasonal and sex-related variability of biomarkers in carp (Cyprinus carpio L.) from Karakaya Dam Lake, Turkey. Environ Toxicol Pharmacol 31 (3):347-356. doi:10.1016/j.etap.2010.12.004

Humphrey CA, King SC, Klumpp DW (2007) A multibiomarker approach in barramundi (Lates calcarifer) to measure exposure to contaminants in estuaries of tropical North Queensland. Mar Pollut Bull 54 (10):1569-1581. doi:10.1016/j.marpolbul.2007.06.004

Johnson LL, Stehr CM, Olson OP, Myers MS, Pierce SM, Wigren CA, McCain BB, Varanasi U (1993) Chemical contaminants and hepatic lesions in winter flounder (Pleuronectes americanus) from the northeast coast of the United States. Environ Sci Technol 27 (13):2759-2771

Kerambrun E, Henry F, Marechal A, Sanchez W, Minier C, Filipuci I, Amara R (2012) A multibiomarker approach in juvenile turbot, Scophthalmus maximus, exposed to contaminated sediments. Ecotox Environ Safe 80:45-53. doi:10.1016/j.ecoenv.2012.02.010

Khan RA, Payne JF (2002) Some factors influencing EROD activity in winter flounder (Pleuronectes americanus) exposed to effluent from a pulp and paper mill. Chemosphere 46 (2):235-239. doi:10.1016/s0045-6535(01)00125-4

Kirby MF, Matthiessen P, Neall P, Tylor T, Allchin CR, Kelly CA, Maxwell DL, Thain JE (1999) Hepatic EROD activity in flounder (Platichthys flesus) as an indicator of contaminant exposure in English estuaries. Mar Pollut Bull 38 (8):676-686

Klaassen CD, Liu J, Choudhuri S (1999) METALLOTHIONEIN: An Intracellular Protein to Protect Against Cadmium Toxicity. Annu Rev Pharmacol Toxicol 39 (1):267-294. doi:doi:10.1146/annurev.pharmtox.39.1.267

Lair S, Mailhot Y, Higgins R, Belanger D, Berthiaume L, deLafontaine Y, Martineau D (1997) Jaw ulcers in Atlantic tomcod, Microgadus tomcod (Walbaum), from the St Lawrence River. J Fish Dis 20 (1):11-17

Lambert Y, Dutil J-D (1997) Can simple condition indices be used to monitor and quantify seasonal changes in the energy reserves of cod (Gadus morhua)? Can J Fish Aquat Sci 54 (S1):104-112. doi:doi:10.1139/f96-149

Lambert Y, Dutil J-D, Munro J (1994) Effects of Intermediate and Low Salinity Conditions on Growth Rate and Food Conversion of Atlantic Cod (Gadus morhua). Can J Fish Aquat Sci 51 (7):1569-1576. doi:doi:10.1139/f94-155 
Linde-Arias AR, Inacio AF, Novo LA, de Alburquerque C, Moreira JC (2008) Multibiomarker approach in fish to assess the impact of pollution in a large Brazilian river, Paraiba do Sul. Environ Pollut 156 (3):974-979. doi:10.1016/j.envpol.2008.05.006

Low KW, Sin YM (1998) Effects of mercuric chloride and sodium selenite on some immune responses of blue gourami, Trichogaster trichopterus (Pallus). Sci Total Environ 214 (1-3):153-164. doi:10.1016/s0048-9697(98)00061-8

Marijić VF, Raspor B (2006) Age- and tissue-dependent metallothionein and cytosolic metal distribution in a native Mediterranean fish, Mullus barbatus, from the Eastern Adriatic Sea. Comparative Biochemistry and Physiology Part C: Toxicology \&amp; Pharmacology 143 (4):382-387. doi:10.1016/j.cbpc.2005.05.019

Michaud MH, Pelletier É (2006) Sources and fate of butyltins in the St. Lawrence Estuary $\begin{array}{ll}\text { ecosystem. Chemosphere } & \\ \text { doi:10.1016/j.chemosphere.2005.12.002 }\end{array}$

Miller KA, Addison RF, Bandiera SM (2004) Hepatic CYP1A levels and EROD activity in English sole: biomonitoring of marine contaminants in Vancouver Harbour. Mar Environ Res 57 (1-2):37-54. doi:10.1016/s0141-1136(03)00059-x

Nunez R (2001) DNA measurement and cell cycle analysis by flow cytometry. Current issues in molecular biology 3:67-70

Olivares A, Quiros L, Pelayo S, Navarro A, Bosch C, Grimalt JO, Fabregat MD, Faria M, Benejam L, Benito J, Sole M, Barata C, Pina B (2010) Integrated biological and chemical analysis of organochlorine compound pollution and of its biological effects in a riverine system downstream the discharge point. Sci Total Environ 408 (22):55925599. doi:10.1016/j.scitotenv.2010.08.009

Payette Y, Lachapelle M, Daniel C, Bernier J, Fournier M, Krzystyniak K (1995) Decreased interleukin-2 receptor and cell cycle changes in murine lymphocytes exposed in vitro to low doses of cadmium chloride. International Journal of Immunopharmacology 17 (3):235-246. doi:10.1016/0192-0561(95)00001-i

Rotchell JM, Clarke KR, Newton LC, Bird DJ (2001) Hepatic metallothionein as a biomarker for metal contamination: age effects and seasonal variation in European flounders (Pleuronectes flesus) from the Severn Estuary and Bristol Channel. Mar Environ Res 52 (2):151-171. doi:10.1016/s0141-1136(00)00270-1

Saint-Louis R, Gobeil C, Pelletier E (1997) Le Tributyletain et Ses Produits de Degradation Dans L'Estuaire du Saint-Laurent (Canada) Tributyltin and Its Degradation Products in the St Lawrence Estuary (Canada). Environmental Technology 18 (12):1209-1218. doi:10.1080/09593330.1997.9618601 (in French)

Sanchez-Dardon J, Voccia I, Hontela A, Chilmonczyk S, Dunier M, Boermans H, Blakley B, Fournier M (1999) Immunomodulation by heavy metals tested individually or in mixtures in rainbow trout (Oncorhynchus mykiss) exposed in vivo. Environmental Toxicology and Chemistry 18 (7):1492-1497

Saucier FJ, Roy F, Gilbert D, Pellerin P, Ritchie H (2003) Modeling the formation and circulation processes of water masses and sea ice in the Gulf of St. Lawrence, Canada. J Geophys Res 108 (C8):3269. doi:10.1029/2000jc000686

Scott WB, Scott MG (1988) Atlantic fishes of Canada, vol 219. University of Toronto Press Toronto

Smith CE, Peck TH, Klauda J, McLaren JB (1979) Hepatomas in Atlantic tomcod Microgadus tomcod (Walbaum) collected in the Hudson River estuary in New York. Journal of Fish Diseases 2 (4):313-319

Smith L, Conrad H (1956) A study of the kinetics of the oxidation of cytochrome c by cytochrome c oxidase. Arch Biochem Biophys 63 (2):403-413. doi:10.1016/00039861(56)90055-8

Sorrentino C, Roy NK, Courtenay SC, Wirgin I (2005) Co-exposure to metals modulates CYP1A mRNA inducibility in Atlantic tomcod Microgadus tomcod from two populations. Aquat Toxicol 75 (3):238-252 
Sweet LI, Zelikoff JT (2001) Toxicology and immunotoxicology of mercury: A comparative review in fish and humans. Journal of Toxicology and Environmental Health-Part BCritical Reviews 4 (2):161-205. doi:10.1080/10937400117236

Tahir A, Secombes CJ (1995) The effects of diesel oil-based drilling mud extracts on immune responses of rainbow trout. Arch Environ Contam Toxicol 29 (1):27-32. doi:10.1007/bf00213083

Théron M, Guerrero F, Sebert P (2000) Improvement in the efficiency of oxidative phosphorylation in the freshwater eel acclimated to $10.1 \mathrm{MPa}$ hydrostatic pressure. Journal of Experimental Biology 203 (19):3019-3023

van der Oost R, Beyer J, Vermeulen NPE (2003) Fish bioaccumulation and biomarkers in environmental risk assessment: a review. Environ Toxicol Pharmacol 13 (2):57-149

Viarengo A, Bettella E, Fabbri R, Burlando B, Lafaurie M (1997) Heavy metal inhibition of EROD activity in liver microsomes from the bass Dicentrarchus labrax exposed to organic xenobiotics: Role of GSH in the reduction of heavy metal effects. Mar Environ Res 44 (1):1-11. doi:10.1016/s0141-1136(96)00097-9

Villeneuve G (1959) Bref aperçu climatique du Québec méridional. Cahiers de géographie du Québec 3 (6) (in French)

Wersto RP, Chrest FJ, Leary JF, Morris C, Stetler-Stevenson M, Gabrielson E (2001) Doublet discrimination in DNA cell-cycle analysis. Cytometry 46 (5):296-306. doi:10.1002/cyto.1171

Williams PJ, Courtenay SC, Wilson CE (1998) Annual sex steroid profiles and effects of gender and season on cytochrome P450 mRNA induction in atlantic tomcod (Microgadus tomcod). Environmental Toxicology and Chemistry 17 (8):1582-1588. doi:10.1002/etc.5620170820

Wirgin I, Roy NK, Loftus M, Chambers RC, Franks DG, Hahn ME (2011) Mechanistic Basis of Resistance to PCBs in Atlantic Tomcod from the Hudson River. Science 331 (6022):1322-1325. doi:10.1126/science.1197296

Wirgin I, Waldman JR (1998) Altered gene expression and genetic damage in North American fish populations. Mutat Res-Fundam Mol Mech Mutagen 399 (2):193-219

Wirgin II, Grunwald C, Courtenay S, Kreamer GL, Reichert WL, Stein JE (1994) A biomarker approach to assessing xenobiotic exposure in Atlantic tomcod from the North American Atlantic coast. Environ Health Perspect 102 (9):764

Xstrata Copper Canada (2012) Closing the Murdochville site. Leaving a positive, sustainable legacy.

Xu W, Charles IG, Moncada S (2005) Nitric oxide: orchestrating hypoxia regulation through mitochondrial respiration and the endoplasmic reticulum stress response. Cell Res 15 (1):63-65

Xu Y, Zhang J, Li W, Schramm KW, Kettrup A (2002) Endocrine effects of sublethal exposure to persistent organic pollutants (POPS) on silver carp (Hypophthalmichthys molitrix). Environ Pollut 120 (3):683-690

Yuan Z, Courtenay S, Chambers RC, Wirgin I (2006) Evidence of Spatially Extensive Resistance to PCBs in an Anadromous Fish of the Hudson River. Environ Health Perspect 114 (1)

Yuan Z, Wirgin M, Courtenay S, Ikonomou M, Wirgin I (2001) Is hepatic cytochrome P4501A1 expression predictive of hepatic burdens of dioxins, furans, and PCBs in Atlantic tomcod from the Hudson River estuary? Aquat Toxicol 54 (3-4):217-230

Yurkowi EJ, Makhijani PR (1998) Flow cytometric determination of metallothionein levels in human peripheral blood lymphocytes: utility in environmental exposure assessment. Journal of Toxicology \& Environmental Health: Part A 54 (6):445-457. doi:10.1080/009841098158737 


\section{Figures}

Figure 1 : The four sampling sites in the St Lawrence Estuary, Québec (CANADA)

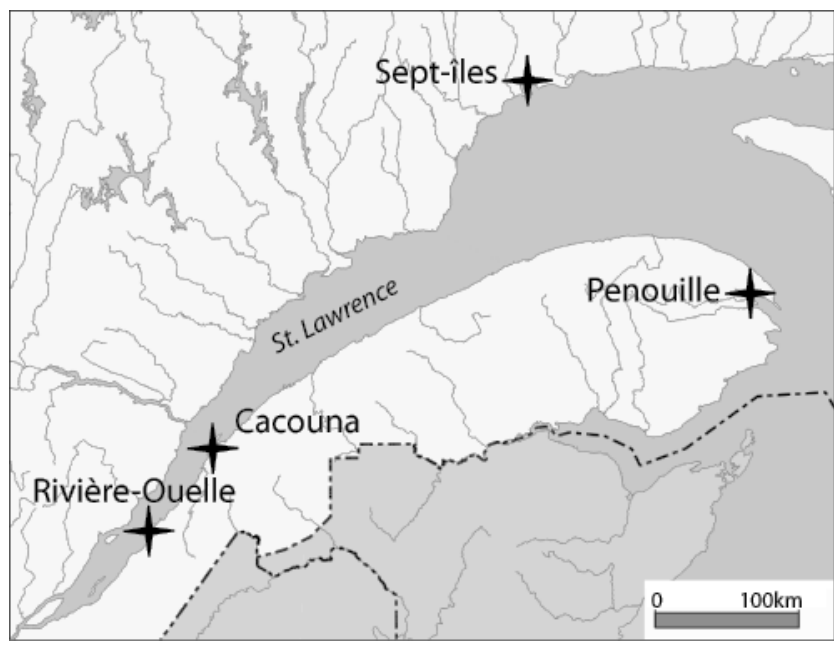

Figure 2 : Total length of different age groups of tomcods sampled in Sept-Îles, Penouille, Cacouna and Rivière-Ouelle.

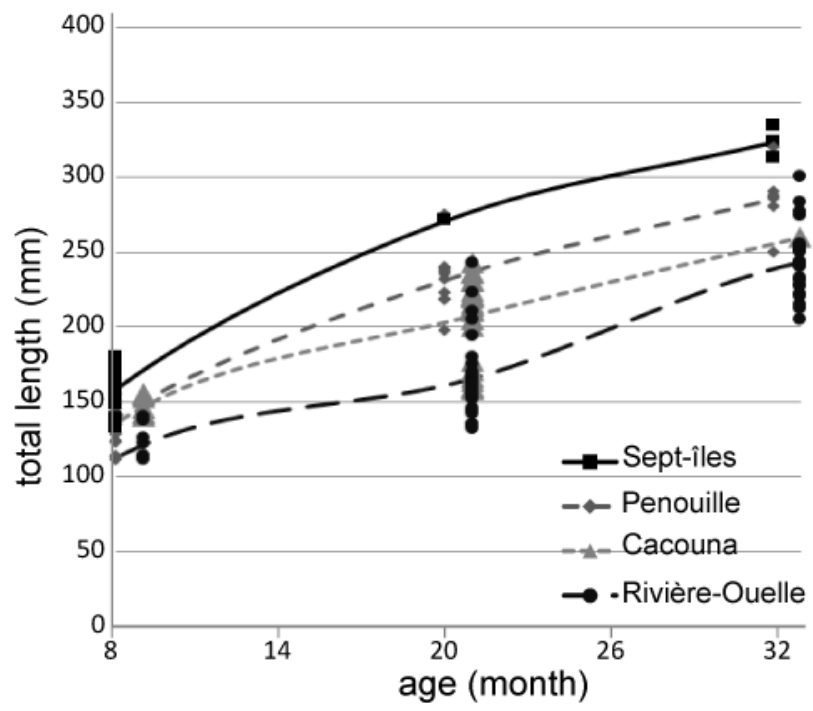


Figure 3 : Biometric indices of tomcod from Rivière-Ouelle ( R), Cacouna (C), Sept-Îles (S), and Penouille $(P)$, considering immature (i) and maturing fishes $(m)$. A: condition factor $(C F)$, $\mathrm{B}$ : female gonadosomatic index (GSI), C: hepatosomatic index (HSI).

(Statistics: lower-case letters indicate significant differences between immature populations; capital letters indicate significant differences between maturing populations; asterisks indicate significant differences between immature and maturing fishes from the same site with $\mathrm{P}<0.05$ )

(A)

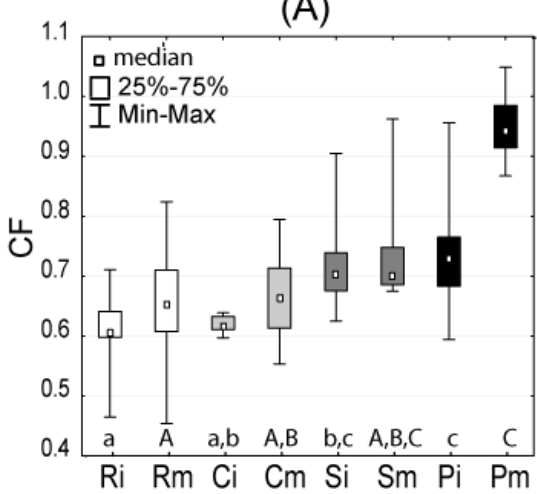

(B)

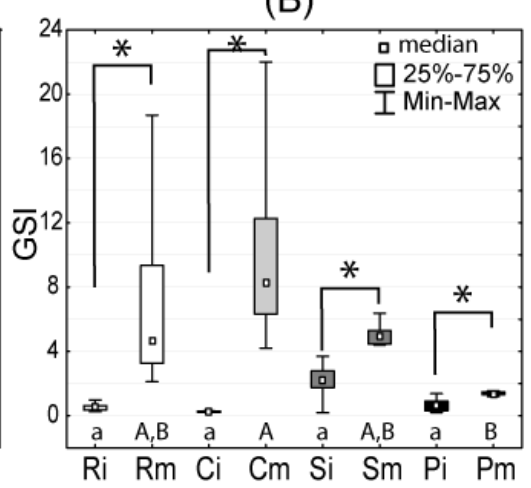

(C)

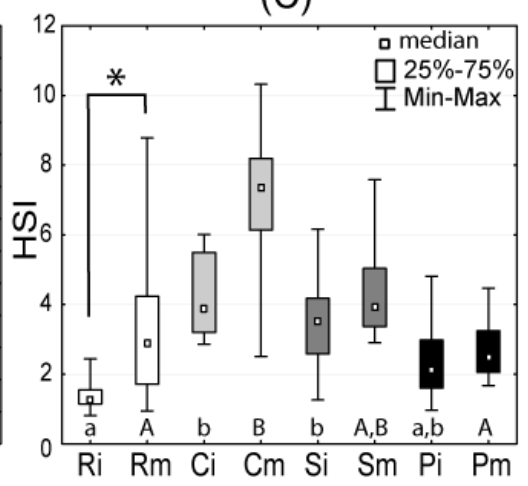

Figure 4 : Assessment of biomarkers on tomcod from Rivière-Ouelle ( R), Cacouna (C), Septîles (S), and Penouille (P), immature (i) and maturing fishes (m). A: EROD activity (pmoles resorufin $/ \mathrm{min} / \mathrm{mg}$ protein), B: Metallothionein induction (mean of fluorescence of pronephric cells suspension).

(Statistics: lower-case letters indicate significant differences between immature populations; capital letters indicate significant differences between maturing populations; asterisks indicate significant differences between immature and maturing fishes from the same site with $\mathrm{P}<0.05)$
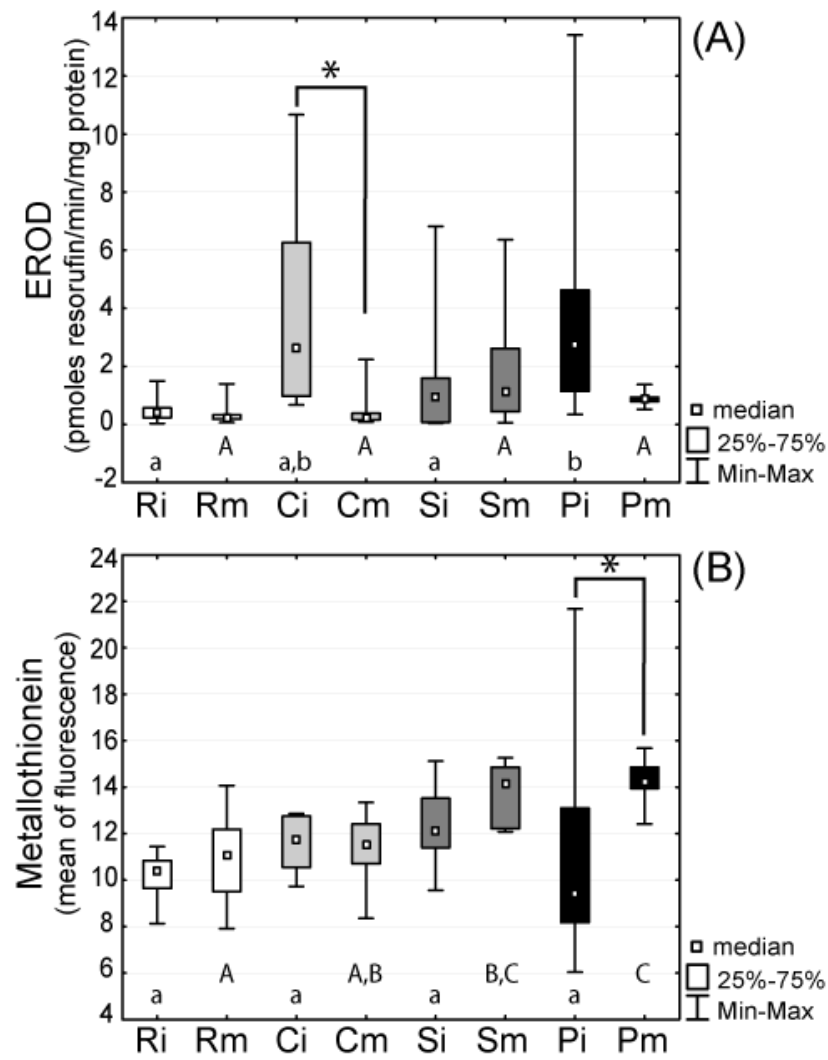
Figure 5 : Assessment of immune biomarkers on tomcod from Rivière-Ouelle ( $R)$, Cacouna $(C)$, Sept-Îles (S), and Penouille (P), immature (i) and in maturation (m). A: cellular cycle (percentage of cells in lymphocyte gate in $\mathrm{G} 2 / \mathrm{M}, \mathrm{S}$ and $\mathrm{G} 0 / \mathrm{G} 1$ phase), B: phagocytosis capacity (percentage of cells that have engulfed three beads and more).

(Statistics: lower-case letters indicate significant differences between immature populations; capital letters indicate significant differences between maturing populations; with $\mathrm{P}<0.05$ )
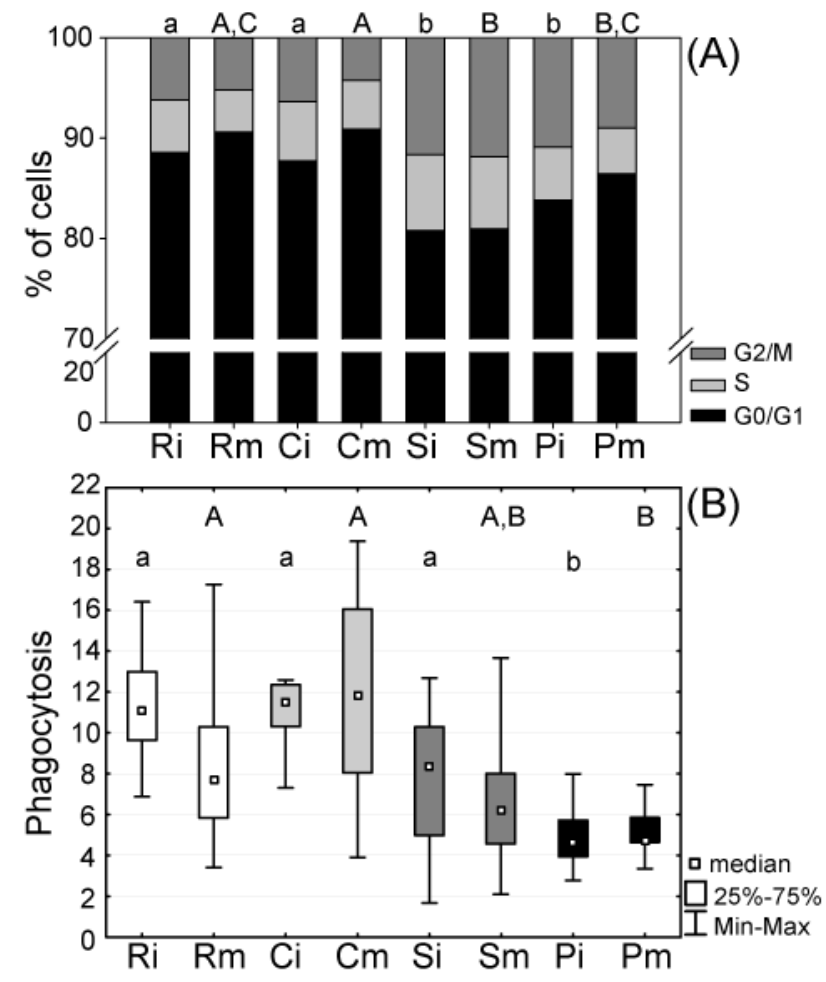

Figure 6 : Principal Component Analysis (PCA): distribution of the variables on the correlation circle (CF: condition factor, EROD, metallothionein, capacity of phagocytosis, cell cycle: \% of lymphocyte in G2/M phase, CCO: enzymatic activity of the Cytochrome C Oxydase).

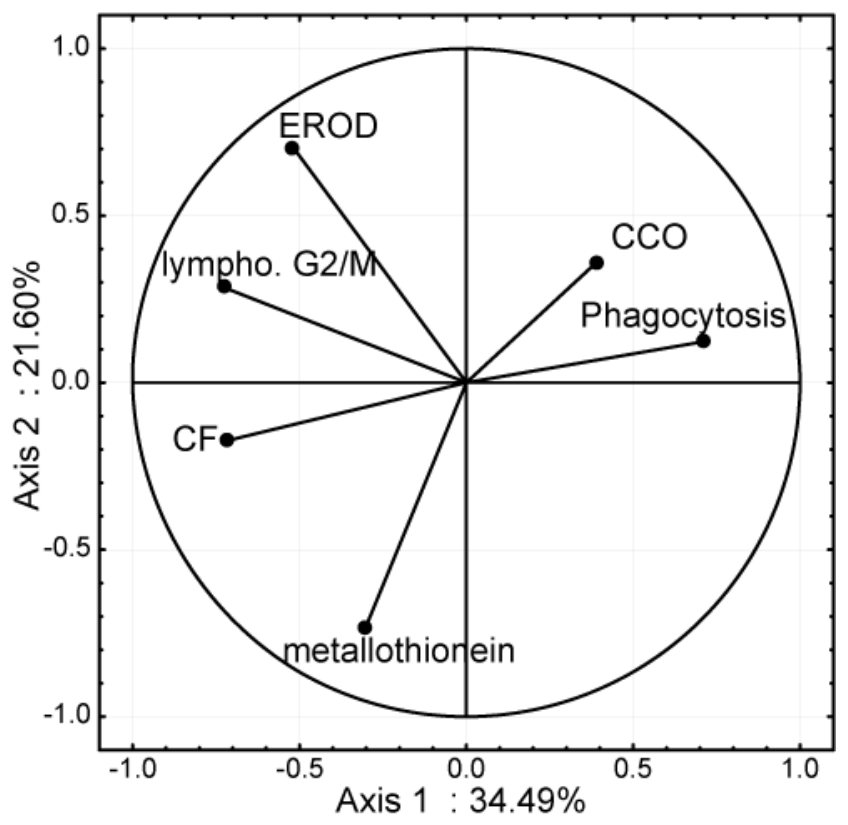


Figure 7 : Principal Component Analysis (PCA): distribution of the individuals (fishes) on the main factorial plan.

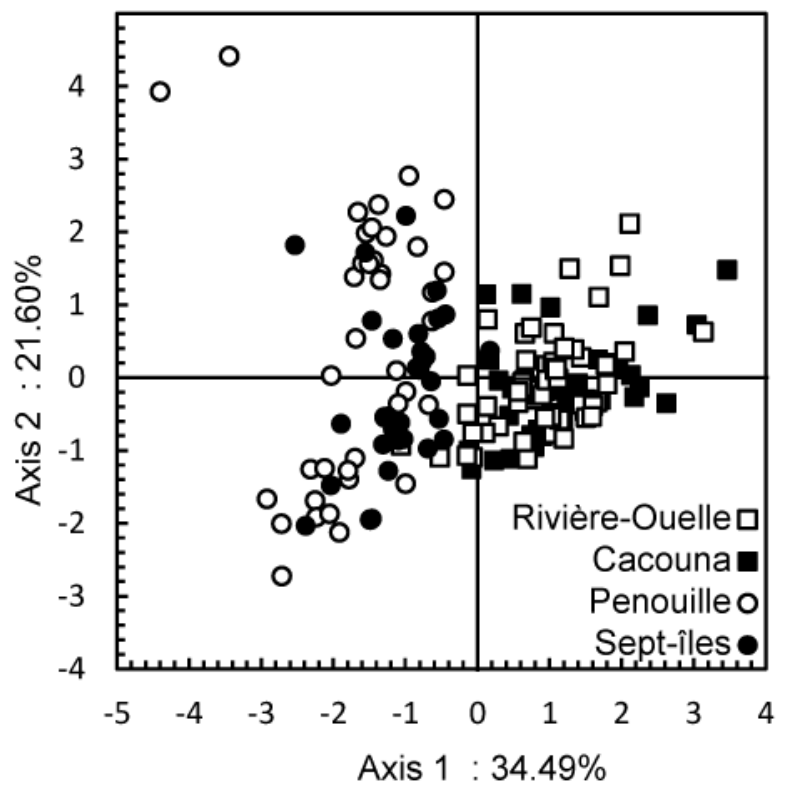

